\title{
Erratum to: Mobility of selected trace elements in Mediterranean red soil amended with phosphogypsum: experimental study
}

\author{
Lina Nafeh Kassir • Talal Darwish • \\ Amin Shaban • Naim Ouaini
}

Published online: 29 October 2011

(C) Springer Science+Business Media B.V. 2011

\section{Erratum to: Environ Monit Assess \\ DOI 10.1007/s10661-011-2272-7}

An author was included in the author list in error. The following author should be removed from the author list: Bruno Lartiges.

The correct author list should therefore read:

Lina Nafeh Kassir, Talal Darwish, Amin Shaban, and Naim Ouaini

The online version of the original article can be found at http:// dx.doi.org/10.1007/s10661-011-2272-7.

L. N. Kassir • N. Ouaini

Faculty of Sciences, URA GREVE CNRS/USEK/UL,

University of Holy Spirit Kaslik,

BP 446, Jounieh, Lebanon

L. N. Kassir $(\bowtie)$

Laboratoire Environnement et Minéralurgie,

(LEM-ENSG/CNRS-INPL),

Institut National Polytechnique de Lorraine - Nancy,

BP 40-54 501, Pole de l'Eau, 15, Avenue du Charmois,

Vandoeuvre, France

e-mail: rmelkassir@darbeirut.com

T. Darwish $\cdot$ A. Shaban

Centre of Remote Sensing,

National Council for Scientific Research, CNRS,

P.O. Box 11-8281, Riadh El Solh,

11072260 Beirut, Lebanon 